
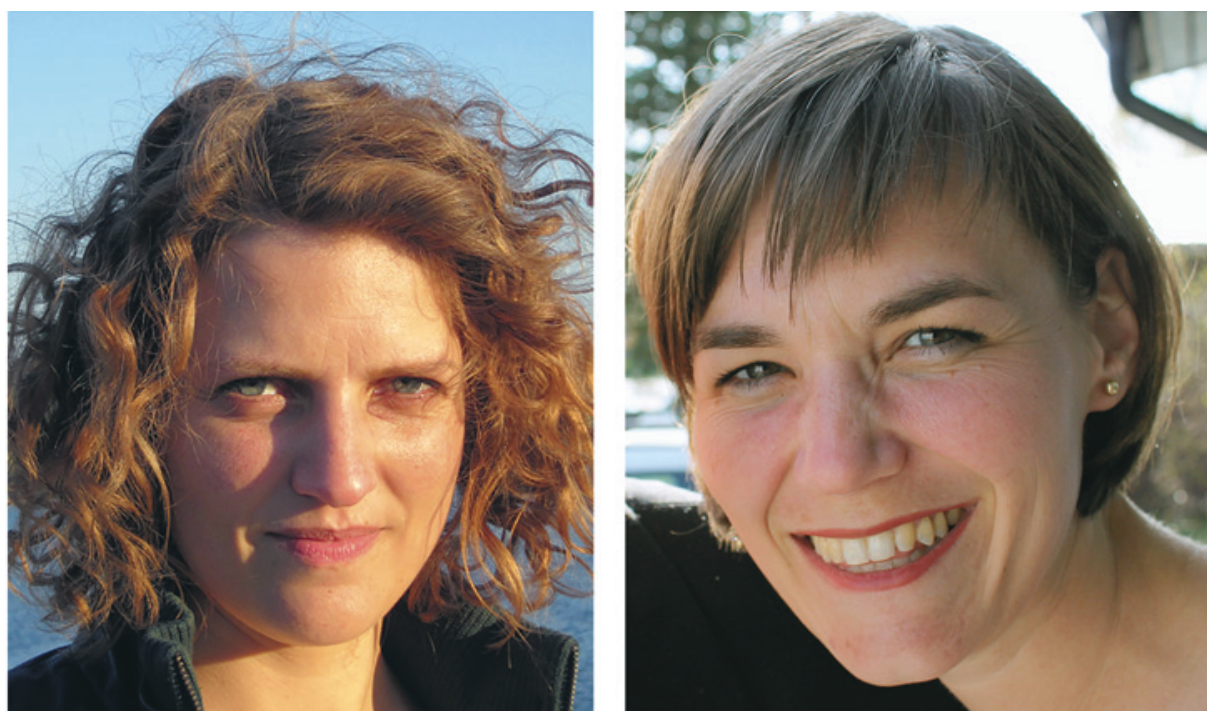

Artikkelens førsteforfatter Miriam F. van Oostwaard (foto: privat) og medforfatter Camilla Haavaldsen (foto: privat)

\title{
Høyt blodtrykk også i neste svangerskap?
}

En femdel av kvinner med hypertensive svangerskapskomplikasjoner i første svangerskap vil få det på nytt ved neste graviditet, men ofte i mildere grad.

Hypertensive svangerskapskomplikasjoner forekommer i $2-8 \%$ av alle svangerskap og er en av de vanligste årsakene til mødredødelighet. Studier har vist svært varierende risiko for å få slike komplikasjoner også i neste svangerskap, fra noen få prosent til hele $65 \%$. I en nylig publisert metaanalyse, med bidrag fra Norge, har man undersøkt risikoen for å få hypertensive svangerskapskomplikasjoner i neste svangerskap (1).

Analysen var basert på individuelle data fra 22 studier og datafiler med til sammen nesten 100000 kvinner med hypertensive svangerskapskomplikasjoner i første svangerskap og som ble gravid på nytt. Risikoen for å få hypertensive svangerskapskomplikasjoner også i neste svangerskap var 20,7 \%, men sykdommen var ofte av mildere art. Risikoen for å få preeklampsi var 13,8\%, svangerskapshypertensjon $8,6 \%$ og HELLPsyndrom (hemolyse, økte serumnivåer av leverenzymer og trombocytopeni) $0,2 \%$. HELLP-syndrom eller fødsel av et barn som var lite for alderen i første svangerskap økte risikoen. Kvinner som hadde normalt blodtrykk før svangerskapet og med hypertensive svangerskapskomplikasjoner i to svangerskap, hadde økt risiko for å utvikle kronisk hypertensjon etter svangerskapet.

- Kunnskap om gjentakelsesrisiko er viktig når leger skal gi råd til kvinner som tidligere har hatt hypertensive svangerskapskomplikasjoner og som vurderer nytt svangerskap, sier Camilla Haavaldsen. Hun er lege ved Akershus universitetssykehus og norsk medforfatter av studien.
- Studier blant kvinner som har avstått fra et nytt svangerskap etter hypertensive komplikasjoner i første svangerskap, viser at nesten en tredel gjorde dette av frykt for slike komplikasjoner også i neste svangerskap. Denne metaanalysen kan være et nyttig verktøy for fødselsleger som arbeider med prekonsepsjonell rådgivning. Kvinner bør ikke nødvendigvis frarådes et nytt svangerskap etter å ha hatt hypertensive svangerskapskomplikasjoner første gang, sier Haavaldsen.

\section{Multinasjonalt samarbeid}

Forfatterne av de 22 studiene som inngikk i metaanalysen, kommer fra 11 land. Databasen er den hittil største som er brukt til å studere gjentakelsesrisikoen for hypertensive svangerskapskomplikasjoner. Sisteforfatter av den norske studien som ble inkludert i metaanalysen, er professor Anne Eskild ved Universitetet i Oslo. Camilla Haavaldsen organiserte og klargjorde den norske delen av datafilen og bidro til revisjon av manuskriptet. Hun har forsket på intrauterin fosterdød, arbeider som lege i spesialisering ved Kvinneklinikken, Akershus universitetssykehus og disputerte i 2014.

\section{Lise Mørkved Helsingen}

Tidsskriftet

\section{Litteratur}

1. van Oostwaard MF, Langenveld J, Schuit E et al. [287-POS]: Recurrence of hypertensive disorders of pregnancy, an individual patient data meta-analysis. Pregnancy Hypertens 2015; 5: 143.
Ordforklaringer

Hypertensive svangerskapskomplikasjoner: Defineres i studien som svangerskapshyper tensjon, preeklampsi, tilleggspreeklampsi (superimposed preeclampsia) og HELLP-syndrom.

HELLP-syndrom: $\mathrm{H}$ = hemolyse, $\mathrm{EL}=$ elevated liver enzymes, LP = low platelets

Small for gestational age (SGA): Barn som er født små (under 10-prosentilen) i forhold til svangerskapsalder.

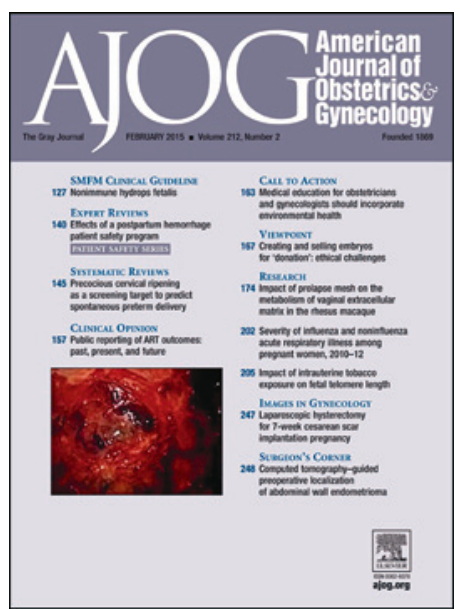

Artikkelen ble e-publisert i det velrennomerte tidsskriftet American Journal of Obstetrics and Gynecology 5.2. 2015 